\title{
Onion as Vegetable Intercrop in Mango Mother Tree Orchard Augments Yield and Economic Return
}

\author{
Sangeeta Kumari $^{*}$, Satish Kumar ${ }^{2}$ and Kavita ${ }^{3}$ \\ ${ }^{1}$ Agricultural Research Institute, Lohia Nagar, Patna - 800 020, Bihar, India \\ ${ }^{2}$ Nalanda College of Horticulture, Noorsarai, Nalanda - 803 113, Bihar, India \\ ${ }^{3}$ Department of Botany and Plant Physiology, Faculty of Basic Sciences and Humanities, \\ DRPCAU, Pusa, Samastipur - 848 125, Bihar, India \\ *Corresponding author
}

\begin{tabular}{|l|}
\hline K e y w o r d s \\
$\begin{array}{l}\text { Equivalent yield, Factor } \\
\text { productivity, } \\
\text { Intercropping, Mango } \\
\text { mother orchard, } \\
\text { Production efficiency }\end{array}$ \\
\hline Article Info \\
\hline $\begin{array}{l}\text { Accepted: } \\
\text { 26 February } 2018 \\
\text { Available Online: } \\
\text { 10 March } 2018\end{array}$ \\
\hline
\end{tabular}

\section{A B S T R A C T}

Field studies were conducted for three consecutive Rabi seasons during 2014 to 2017 in a 30 -year old mango mother orchard where trees were not allowed to bear fruit and only scion materials were obtained for grafting purpose to get planting materials of mango. The orchard trees are planted at a distance of $10 \times 10 \mathrm{~m}$. The eight different vegetable intercrops viz., garlic (Local variety), pea (Azad P-1), carrot (Pusa kesar), palak (All green), coriander (Pant haritima), onion (Patna red), radish (Snow white) and French bean (P-44) were grown in the orchard. The trial was conducted in a randomized block design, each treatment replicated thrice. Based on pooled mean yield of intercrops over three years, result indicated that yield of different intercrops varied significantly and the maximum yield $(206.07 \mathrm{q} / \mathrm{ha})$ was recorded in palak followed by onion $(197.78 \mathrm{q} / \mathrm{ha})$. The lowest yield was recorded in coriander ( $51.33 \mathrm{q} / \mathrm{ha})$. The net income in Indian Rupee per hectare was the highest in onion intercrop $(2,40,052)$ followed by garlic $(1,73,124)$. The maximum benefit cost ratio (3.14) was recorded in onion intercrop. The highest partial factor productivity of applied nitrogen $(197.78 \mathrm{~kg}$ yield/ $\mathrm{kg} \mathrm{N})$ and substantially higher economic efficiency (2000.43 Rs./ha/day) was also recorded in onion intercrop. Thus, the result demonstrated that intercropping of vegetables particularly onion in mango mother tree orchard is a highly remunerative proposition augmenting yield and economic return to farmers..

\section{Introduction}

Mango is one of the most important and widely cultivated tropical fruits of the world. In India it is grown in an area of 23.78 lakh hectares with an annual production of 161.98 lakh tones (NHB, 2012). This contributes to 37.8 per cent of total area and 18.6 percent of total production of fruit crops in India. The mango trees spaced at a distance of $10 \times 10 \mathrm{~m}$ provides ample scope for growing of short duration, location specific and market driven crops grown as intercrops. More than one intercrop can also be grown to efficiently utilize the space and other natural resources. The intercrops not only generate an extra income but also this practice may help to check soil erosion through ground cover, 
improving physico-chemical properties of soils. Intercropping is one of the techniques of land utilization for optimum production (Bhatnagar et al., 2007) which can provide substantial yield advantage compared with sole cropping.

There is no scope for horizontal land expansion in the country. However, it could be manifold extended vertically considering different layer of agro-forestry system, which are applicable to small holding to provide maximum returns as land sustainability (Singh and Osman, 1987). In the mother orchard of mango, trees are wide spaced and only scion is taken for grafting purpose and fruits are not taken, hence there is no problem of shading to intercrop vegetables. Intercropping in mango mother orchard may be a good proposition towards achieving the goal of doubling farmers' income which is now being emphasized. Therefore, studies were conducted with the objective to find suitable intercrop to be grown in mango mother orchard during Rabi season, by growing vegetable intercrops and the economics of cultivation was worked out.

\section{Materials and Methods}

The experiment was conducted in the 30-year old mango mother orchard located at Agricultural Research Institute, Patna (under administrative control of Bihar Agricultural University, Sabour, Bhagalpur) during Rabi seasons of 2014-2017. The soil of the experimental orchard was medium black clay loam of average fertility and well drained having $\mathrm{pH}$ 7.5. It is tenaciously sticky when wet and hard when dry. The experiment was laid out in a randomized block design (RBD) with plot size $3 \times 3 \mathrm{~m}$ leaving $3 \mathrm{~m}$ space from the trunk of each tree. There were eight different vegetable crops grown as intercrops which were considered as eight different treatments and these were replicated thrice. The economic produce of vegetables from each plots were harvested and quantified per hectare of mango mother tree orchard. Uniform cultural operations and recommended packages of practices were given to all the intercropped vegetables. The intercrop and agro-techniques followed for their cultivation is given in table 1 .

Economics of different mango based intercropping system was worked out taking into account the prevailing cost of inputs like labour, seeds, manures and fertilizers, pesticides and sale price of produce during 2014-15, 2015-16 and 2016-17. The cost of various inputs and sale price of produce differed slightly during the three consecutive years. Hence the cost of cultivation of different crops was worked out as average of 2014-15, 2015-2016 and 2016-2017. The gross return was calculated by multiplying the average yield (q/ha) of different crops during the three years of study with prevailing market price per quintal and net returns was worked out by deducting the cost of cultivation from gross return. The benefit-cost ratio $(\mathrm{B}: \mathrm{C})$ of intercropping systems were worked out to know the most remunerative and profitable intercropping system using the formula given below:

B: $\mathrm{C}$ ratio $=\frac{\text { Gross return from intercropping system }}{\text { Cost of cultivation of intercropping system }}$

To compare yield and profitability of intercrops their economic equivalent yield in terms of garlic crop called garlic equivalent yield (GEY) was computed using the formula given by Ahlawat and Sharma (1993) where GEY $(\mathrm{q} / \mathrm{ha})=$ yield of test crop $(\mathrm{kg} / \mathrm{ha}) \times$ price of test crop (Rs./kg)/ price of garlic (Rs./kg). Further to know per day productivity of the crop under a particular treatment, production efficiency ( $\mathrm{kg} / \mathrm{ha} /$ day) and also economic efficiency (Rs/ha/day) was calculated based on crop duration. The nutrient use efficiency under different intercropping treatments in terms of partial factor productivity of nitrogen 
( $\mathrm{kg}$ yield/kg $\mathrm{N}$ applied) was worked out in the experimental trial. All the data were subjected to analyses of variance (ANOVA) and means were separated with the least significant difference (LSD) at 5\% profitability. All statistical analysis was performed with the help of the SPSS 11.0 statistical software.

\section{Results and Discussion}

\section{Yield and economics of vegetable intercrops}

The data on yield and economics of cultivation revealed that all the intercrops differed significantly with respect to yield (Table 2). The maximum yield (206.07 q/ha) was recorded in palak intercrop followed by onion (197.78 q/ha) and the lowest yield was recorded in coriander $(51.33 \mathrm{q} / \mathrm{ha})$ which was at par with French bean (54.81 q/ha). The highest gross returns (316448 Rs./ha), net returns (240052 Rs./ha) and BC ratio (3.14) were realized with onion intercrop in mango mother orchard which was significantly superior to all other treatments while the lowest was recorded in pea intercrop which was significantly less than all other intercrops. This was due to higher intercrop yield vis-àvis prevailing sale price of the produce. These findings are in consonance with the results of Korikanthimath et al., (1995). Wide variation in net return among intercrops was also due to variation in the cost of cultivation and this result corroborates with the findings of Jat et al., (2012) and Prasad et al., (2013). Onion recorded the maximum $\mathrm{BC}$ ratio (3.14) followed by palak (2.62) and garlic (2.13). However, the least benefit cost ratio was obtained in pea (1.34). The better performance of onion may be due to congenial micro climate prevailing in the mango mother tree orchard suitable for better utilization of natural resources like light, space, nutrients etc. than that of the sole crop of mango mother tree. The research findings by Thankamani et al., (2010) also reported congenial microclimate in mango mother tree orchard for the cultivation of Amorphophallus (Gajendra), Greater yam (Sreekeerthi), ginger (Varada), and turmeric (Prathiba). When equivalent yield of the intercrops were compared in terms of GEY, data revealed that highest GEY was in onion (79.11) and the lowest was in pea (36.60). This might be due to better conducive soil and micro climatic environment and this in turn resulted in least competition stress for moisture, nutrients, space and solar radiation faced by onion intercropping in mango mother orchard. This leads to better utilization of natural resources like light, space, nutrients etc. and in turn boost up the growth and supply more photosynthates towards the sink and ultimately into higher equivalent yield. The yield and productivity of the intercropping systems depend on the compatibility of the crops introduced as well as nutrient availability and management. The mango trees were beheaded and defoliated in the last week of September to get the new shoot so that shading effect is not the problem.

\section{Effect on production efficiency and economic efficiency}

The results indicated that among different intercrops the productivity was the highest in palak $(206.07 \mathrm{q} / \mathrm{ha})$ intercrop grown in mango mother orchard owing to its larger size and number of leaves but, the maximum production efficiency was with the radish intercrop (235.83 kg/ha/day) owing to shorter crop duration period (Table 3). It is also apparent from the data that the different intercropping treatments had marked variation on net returns and economic efficiency. Intercropping of onion in mango mother orchard had substantially higher economic efficiency (2000.43 Rs./ha/day) as compared to rest of the treatments and the lowest in pea intercrop (698.56 Rs./ha/day). This reflects the higher equivalent yield when onion was taken as intercrop than other winter vegetables. 
Table.1 Agro-techniques adopted for vegetable cultivation in mango mother tree orchard

\begin{tabular}{|c|l|c|c|c|c|}
\hline Treatments & \multicolumn{1}{|c|}{$\begin{array}{c}\text { Crop } \\
\text { duration } \\
\text { (month) }\end{array}$} & $\begin{array}{c}\text { Spacing } \\
(\mathrm{cm})\end{array}$ & $\begin{array}{c}\text { Seed } \\
\text { rate } \\
(\mathrm{kg} / \mathrm{ha})\end{array}$ & $\begin{array}{c}\text { Fertilizer } \\
\text { dose }- \text { NPK } \\
\text { (kg/ha) }\end{array}$ \\
\hline $\mathrm{T}_{1}$ & Garlic (Local variety) & 120 & $15 \times 10$ & 400 & $100: 80: 80$ \\
\hline $\mathrm{T}_{2}$ & Pea (Azad P-1) & 120 & $30 \times 10$ & 45 & $40: 60: 60$ \\
\hline $\mathrm{T}_{3}$ & Carrot (Pusa kesar) & 120 & $25 \times 10$ & 1.5 & $120: 60: 80$ \\
\hline $\mathrm{T}_{4}$ & Palak (All green) & 90 & $30 \times 10$ & 8 & $180: 40: 40$ \\
\hline $\mathrm{T}_{5}$ & Coriander (Pant haritima) & 90 & $30 \times 20$ & 10 & $60: 40: 30$ \\
\hline $\mathrm{T}_{6}$ & Onion (Patna red) & 120 & $15 \times 10$ & 8 & $100: 80: 100$ \\
\hline $\mathrm{T}_{7}$ & Radish (Snow white) & 80 & $25 \times 10$ & 8 & $150: 60: 80$ \\
\hline $\mathrm{T}_{8}$ & French bean (P-44) & 120 & $30 \times 15$ & 80 & $60: 80: 40$ \\
\hline
\end{tabular}

Table.2 Yield and economics of cultivation of vegetable intercrops in mango mother orchard

\begin{tabular}{|c|c|c|c|c|c|c|c|}
\hline Intercrops & $\begin{array}{l}\text { Yield } \\
\text { (q/ha) }\end{array}$ & $\begin{array}{l}\text { Sale price } \\
\text { (Rs./kg.) }\end{array}$ & $\begin{array}{l}\text { Gross } \\
\text { income } \\
\text { (Rs./ha) }\end{array}$ & $\begin{array}{l}\text { Cost of } \\
\text { cultivation } \\
\text { (Rs./ha) }\end{array}$ & $\begin{array}{c}\text { Net } \\
\text { income } \\
\text { (Rs./ ha) }\end{array}$ & $\begin{array}{l}\text { B:C } \\
\text { ratio }\end{array}$ & $\begin{array}{l}\text { GEY } \\
\text { (q/ha) }\end{array}$ \\
\hline Garlic (Local variety) & 63.63 & 40 & 254520 & 81396 & 173124 & 2.13 & 63.63 \\
\hline Pea (Azad P-1) & 58.56 & 25 & 146400 & 62571 & 83829 & 1.34 & 36.60 \\
\hline Carrot (Pusa kesar) & 61.44 & 30 & 184320 & 61846 & 122474 & 1.98 & 46.08 \\
\hline Palak (All green) & 206.07 & 10 & 206070 & 56922 & 149148 & 2.62 & 51.52 \\
\hline $\begin{array}{l}\text { Coriander (Pant } \\
\text { haritima) }\end{array}$ & 51.33 & 30 & 153990 & 54903 & 99087 & 1.80 & 38.50 \\
\hline Onion (Patna red) & 197.78 & 16 & 316448 & 76396 & 240052 & 3.14 & 79.11 \\
\hline Radish (Snow white) & 188.67 & 10 & 188670 & 61435 & 127235 & 2.07 & 47.17 \\
\hline French bean $(\mathrm{P}-44)$ & 54.81 & 50 & 274050 & 104417 & 169633 & 1.62 & 68.51 \\
\hline LSD $(p=0.05)$ & 9.75 & - & - & - & - & - & - \\
\hline $\operatorname{SEm}( \pm)$ & 3.21 & - & - & - & - & - & - \\
\hline
\end{tabular}

Table.3 Production and economic efficiency as influenced by intercropping of winter vegetables in mango mother tree orchard

\begin{tabular}{|c|c|c|c|c|c|}
\hline Treatment & Intercrops & $\begin{array}{l}\text { Yield of } \\
\text { compone } \\
\text { nt crop } \\
\text { (q/ha) }\end{array}$ & $\begin{array}{l}\text { Production } \\
\text { efficiency } \\
\text { (kg/ha/day) }\end{array}$ & $\begin{array}{l}\text { Economic } \\
\text { efficiency } \\
\text { (Rs/ha/day) }\end{array}$ & $\begin{array}{l}\text { Partial factor } \\
\text { productivity of } \\
\text { nitrogen (kg } \\
\text { yield/kg N) }\end{array}$ \\
\hline $\mathbf{T}_{1}$ & Garlic (Local variety) & 63.63 & 53.03 & 1442.70 & 63.63 \\
\hline $\mathbf{T}_{2}$ & Pea (Azad P-1) & 58.56 & 48.80 & 698.56 & 146.40 \\
\hline $\mathbf{T}_{3}$ & Carrot (Pusa kesar) & 61.44 & 51.20 & 1020.60 & 51.22 \\
\hline $\mathbf{T}_{4}$ & Palak (All green) & 206.07 & 228.96 & 1657.20 & 114.48 \\
\hline $\mathbf{T}_{5}$ & $\begin{array}{l}\text { Coriander (Pant } \\
\text { haritima) }\end{array}$ & 51.33 & 57.03 & 1100.96 & 85.55 \\
\hline $\mathrm{T}_{6}$ & Onion (Patna red) & 197.78 & 164.82 & 2000.43 & 197.78 \\
\hline$T_{7}$ & Radish (Snow white) & 188.67 & 235.83 & 1590.43 & 125.78 \\
\hline$T_{8}$ & French bean $(\mathrm{P}-44)$ & 54.81 & 45.68 & 1413.60 & 91.35 \\
\hline
\end{tabular}




\section{Effect on partial factor productivity}

The nutrient use efficiency under different intercropping treatments is discussed in terms of partial factor productivity. The data revealed that the intercropping treatments caused appreciable variation on partial factor productivity of $\mathrm{N}$ in winter vegetables crops when taken as intercrop in mango mother orchard (Table 3). Among all the treatment, intercropping of onion reflected the highest partial factor productivity of applied nitrogen $(197.78 \mathrm{~kg}$ yield $/ \mathrm{kg} \mathrm{N})$ because of lower requirement of nitrogen and higher yield of crop. However, a lower partial factor productivity of $\mathrm{N}$ was observed with carrot intercropped in mother orchard $(51.22 \mathrm{~kg}$ yield/kg N). This was due to higher requirement of nitrogen and lower yield of crop. The partial factor productivity is a very useful index for estimating the fertilizer use efficiency when a control plot yield is not available in the experimental trial.

The success of intercropping systems depends very much on the selection of compatible crop combination and the geometry of the planting in which each crop exploits a destined and different zone of atmosphere and soil. So the competition for moisture, nutrients, space and solar radiation will be the minimum. Intercropping of the vegetables and food crops provides additional income to the farmers and helps in maximization of land use. In addition to this, it has significant role in increasing the productivity and improvement of health of the orchard.

The present investigation indicated that intercropping vegetable crops in the mango mother tree orchard during Rabi season provided very good yield and income. All the intercrops tested were suitable, however the best return was obtained from onion (Patna Red) and also the maximum GEY was recorded in this crop. The results of the studies clearly demonstrated that the intercropping of winter vegetables in mango mother orchard is a highly remunerative proposition towards doubling farmers' income. This study will help the farmers/scientists to select the appropriate intercropping systems in Zone III B of Bihar. However, further studies are necessary for inclusion of various other intercrops for location and soil specific recommendations and to confirm the long term effect of intercropping.

\section{References}

Ahlawat, I.P.S. and Sharma, R.P. 1993. Agronomic Terminology. $3^{\text {rd }}$ Edition, Indian Society of Agronomy, New Delhi, India.

Bhatnagar, P., Kaul, M.K. and Singh, J. 2007. Effect of intercropping in kinnow based production system. Indian Journal of Arid Horticulture 2: 15-17.

Jat, R.A., Dungrani, R.A., Arvadia, M.K. and Sahrawat, K.L. 2012. Diversification of rice (Oryza sativa L.) based cropping systems for higher productivity, resource-use efficiency and economic returns in South Gujarat of India. Archives of Agronomy and Soil Science 58(6): 561-572.

Korikanthimath, V.S., Hedge, Rajendra, Sivaranan, K. and Hedge, R. 1995. Integrated input management in coffee based spices multi-storied cropping system. Indian Coffee 59: 3-6.

NHB. 2012. Indian Horticulture Database 2012. National Horticulture Board, Ministry of Agriculture, Government of India.

Prasad, D., Yadava, M.S. and Singh, C.S. 2013. Diversification of rice (Oryza sativa) based cropping systems for higher productivity, profitability and resource-use-efficiency under irrigated 
ecosystem of Jharkhand. Indian Journal of Agronomy 58(3): 264-270.

Singh, R.P. and Osmen, M. 1987 Agroforestry system for small holdings. International Workshop on Agroforestry for Rural Needs, Vigyan Bhawan, New Delhi, February 22-26.

Thankamani, C.K., Kandiannen, K., Madan, M.S., Hamza, S. and Krishnamurthy,
K.S. 2010. Intercropping of tuber and fodder crops in juvenile black pepper garden. In: Proceedings of National Seminar on Soil, Water and Crop Management for Higher Productivity of Spices, 11-12, Feb.2010, Centre for Water Resources Development and Management, Calicut, India, pp.186190.

\section{How to cite this article:}

Sangeeta Kumari, Satish Kumar and Kavita. 2018. Onion as Vegetable Intercrop in Mango Mother Tree Orchard Augments Yield and Economic Return. Int.J.Curr.Microbiol.App.Sci. 7(03): 3441-3446. doi: https://doi.org/10.20546/ijcmas.2018.703.396 